\title{
FIRST PERFORMANCES
}

\section{Schwetzingen: Adriana Hölszky's 'Der gute Gott von Manhattan'}

Adriana Hölszky - Romanian-born, but Stuttgartbased since 1976 - scored a deserved, significant hit when her first opera, Bremer Freiheit, based on Rainer Maria Faessbinder, was staged at the 1988 Munich Biennale. Two other operas - one based on Jean Genet - had their premières in Vienna and Bonn, before Stuttgart's ever-pioneering Württembergisches Landestheater commissioned Giuseppe e Silvia, based on Hans Neuenfels, in 2000. A sheaf of chamber and orchestral works have seen premières at festivals such as Styria and Vienna, and (even more aptly) at Donaueschingen.

Aptly, because Adriana Hölszky is a pretty much unreconstructed Modernist, whose musical language would sit well in the Boulez, Nono and Stockhausen-dominated early 1960s. In some ways it accords less well with Schwetzingen, a Rhineside mini-Versailles near Mannheim, whose Rococo palace theatre, launched in 1752 with Molière, is one of the most charmingly and endearingly Mozartian of all German venues. Rare Baroque revivals are a speciality. Henze's Elegy for Young Lovers was premièred there in 1961, and Pollicino and The English Cat in 1981/3; while Egk, Fortner, Reimann and, more recently, two new operas by Salvatore Sciarrino are among the 32 opera premières to date, reflecting the Schwetzingen Festival's bold and industrious commissioning policy.

This year's results were mixed: an ear-battering might seem a slightly Napoleonic solution to the 2004 commission. Hölszky's Der gute Gott von Manhattan features a fuzzily elusive, possibly botched libretto culled by the composer from the Klagenfurt-born, Rome-based Existentialist philosopher-poet Ingeborg Bachmann (1926-73) - who was Henze's librettist for Der Junge Lord and the Kleist-based Der Prinz von Homberg. It's a kind of 'if only love could save the world, but it can't death-and-destruction seem the only logical way out', or 'après moi le déluge', nihilistic plot (a dance of death, in fact) centering on two lovers and their dissociated cavortings in a hotel bedroom (actually three bedrooms: they gradually make their way up to the 57 th - i.e. top - floor, before the final balloon goes up (or bomb goes off). Prescient? Maybe.
What worked best in this not over-attractive evening was a highly competent, mildly engaging staging by Stephan Kimmig (also Stuttgart); a vivid 8-part chorus from Dresden's Sächsische Staatsoper (the co-commissioners), who went through their nightmarish antics well; capable singing from the two 'representative' central characters, Jan and Jennifer (former Dresden chorister Andreas Scheibner and Stuttgart-trained Ann-Katrin Naidu). And above all the first-rate playing - including some stunning antiphonal brass/percussion, all the more powerful in such an intimate environment - under conductor Alexander Winterson, John Eliot Gardiner's former assistant at Munich, who also conducted Hölszky's Bremer Freiheit at Stuttgart and later the première of her opera Tragödia in Bonn.

Winterson had no problem making the music speak clear as well as loud, and his players responded ably to the score's wealth of detail. Hölszky has offered a lucid analysis of what she's trying to achieve structurally. The problem is that for the average polite, supportive opera-goer most of this samey Serialist, pathos-devoid stuff goes right over their heads, and doubtless ears too. The two bizarre squirrels' ditties in the vivid 'Marionettentheater' / Bassarids-like interlude, and their superb duet (Birgit Fandrey, Anja Maria Kaftan) when they reappear as policemen, were two of the most bearable bits. Yet any real achievement seemed to defeat itself musically: and what should emerge as an existentialist, slightly Dürrenmatt-like mystery looked all too much like just another nervy excess of German stagecraft. A gypsy Fortune-Teller (Elisabeth Wilke) gets underused, and thus unbalancingly wasted; the good God (Daniel Gloger), when he appears bicycle-borne, is a squawking countertenor: more assault. Hölszky specified the squirrels should be 'shrill, and sharp as a knife.' Frankly, her whole opera sounded a bit like that.

Roderic Dunnett

\section{Lucerne Festival 2004: Harrison Birtwistle}

Among major European festivals, the Lucerne Festival is outstanding in the attention it pays to contemporary music. The latest manifestation of 
this is the founding of an annual Lucerne Festival Academy for young professional players, specializing in the music of the 20th and 21st centuries, under the leadership of Ensemble Intercontemporain and the indefatigable Pierre Boulez. Nor is this is on the modest scale of a 'young Sinfonietta': its final concert, conducted by Boulez, began with Harrison Birtwistle's massive Earth Dances.

The choice of this work was no coincidence, as Birtwistle, in his seventieth birthday year, was the Festival's composer-in-residence. The programme included more than a dozen of his works, though no music-theatre (Lucerne being a notably unoperatic festival). Among them were 'imported' performances of Pulse Shadows, by the familiar Nash/Arditti team, and Theseus Game, by Ensemble Modern, as well as the first complete performance of Orpheus Elegies, by the countertenor Andrew Watts with Heinz and Ursula Holliger. Birtwistle's composer-in-residence status also meant that he was featured in an exhibition of musical portrait photographs spread all over the town, so that one kept coming across his face unexpectedly - often pictured by Betty Freeman in delightfully domestic contexts - in foyers and shop windows. (My favourite shot, though, was of Boulez and a hip-hop d.j., side by side and smiling at the camera, but clearly without either having the faintest idea who the other was.)

On a flying visit, I caught the first two Birtwistle performances of the festival, on 21 August. In the morning, in the light, modern Lukaskirche, the second half of Pierre-Laurent Aimard's piano recital included three of the Harrison's Clocks pieces - interleaved with music by Ligeti, Ravel and Bartók in a continuous sequence suggested by the idea of repetition. The brilliance of the playing matched the inspiration of this 'composed programme', which certainly caught the imagination of a large audience.

That evening, in the magnificent lakeside Konzertsaal, the Cleveland Orchestra and its music director Franz Welser-Möst performed Birtwistle's The Shadow of Night and its brand new companion-piece Night's Black Bird. The former was written in 2001 to a Cleveland Orchestra commission, and first performed under WelserMöst's predecessor Christoph von Dohnányi; it reached the BBC Proms in 2003. The latter is the first in a series of commissions sponsored by the Roche pharmaceutical company, to be unveiled both at the Lucerne Festival and at Carnegie Hall in New York: the 2005 commission has been awarded to Chen Yi. The amount of money involved, not only in the commissioning itself but also in a lavish accompanying book (and in what looked like a seriously glitzy pre-concert party), is clearly enough to make British promoters, grubbing around for enough support to keep composers up to subsistence level, green with envy.

The Shadow of Night is a work which reverts to Birtwistle's old obsession with melancholy hitherto most clearly expressed in Melancolia I (1976), named after a celebrated Dürer engraving. It grows out of the first line of Dowland's bleak lute song In darkness let me dwell - though it can hardly be a coincidence that the opening turning semitone of Dowland's melody corresponds to the start-up motive of so many of Birtwistle's works. This gives rise to a continuous nocturne lasting the best part of half an hour, punctuated by frequent quickenings of tempo to short, violent climaxes, and ending with a striking gesture: a chord on low strings and bells, a single high, loud trumpet note, then as the bells die away two gentle scrapes of the guiro.

Night's Black Bird (the title is taken from another Dowland lute-song, Flow My Tears) inhabits the same nocturnal world, but in Birtwistle's words 'takes listeners on a different route through the same musical landscape' - a familiar analogy in his music, and indeed a familiar procedure both within pieces and from one work to another. Its opening is a slightly more eventful version of the start of The Shadow of Night, and its ending is identical. But, compared to the earlier work, it's shorter (about 12 minutes), and perhaps more obviously evocative of the natural world: the little quickenings of tempo seem to peak in animal screams; the melodic line, shared around high woodwind and at one point in piercing eight-fold unison, takes on the aspect of birdsong.

The performances seemed well-paced and sympathetic, belying the reputation Welser-Möst acquired in his time with the London Philharmonic as no friend of modernism. The Cleveland Orchestra's refined woodwind section could perhaps have summoned up a little more raucousness at times; and even in the pindroppingly clear Konzertsaal acoustic, the harps and some of the percussion didn't always come through enough.

Beforehand, Birtwistle had called Night's Black Bird a 'postscript' to The Shadow of Night, and suggested it should be performed after it, separated by a performance of the Dowland song. At a late stage, the order was reversed, pointing up the fact that the two works are in parallel rather than in series, and creating a satisfying shaped and varied sequence. (The dyspeptic critic who, after the Edinburgh Festival performance a few days later, described it as 'the glummest 50 minutes you are likely to spend in a 
concert hall' could hardly have been listening very closely - but then he also called the singlemovement The Shadow of Night a 'suite'). Presumably this will now be the standard format for future performances. But I hope symphony orchestras will also consider programming Night's Black Bird on its own, as a short and immediately appealing Birtwistle 'taster' for general audiences. 'Birtwistle without tears', you might call it - except that in view of the subjectmatter it's more like 'Birtwistle with tears'.

Anthony Burton

\section{Pula, Croatia: Balkans’ Summer Music Camp}

The Balkans' Summer Music Camp ${ }^{1}$ was first established in 1995. Nigel Osborne's initiative was to address the needs of children who had been victims of trauma caught in conflict and warlocked zones in the former Yugoslavia. Through a professional exchange with Nigel Osborne last year at the Cambridge Music Conference, my sister Catherine Carmack (12.10.57-12.12.03) decided to work as a volunteer at the camp this summer. Owing to her untimely death I went in her place, to observe the creative and curative process of the children's development. About 35 children from the Special School of Mostar, Bosnia Herzegovina came to the Adriatic for a week's vacation on the coast of Croatia. Most of these children live in an orphanage in Mostar, but are receiving music therapy through the Pavarotti Music Centre. Although most of the children were attended by carers, a few of the children were accompanied by their mothers. Many of the children are primarily suffering from exposure to violence and remain traumatized. Some of them have special needs including Down's Syndrome; two were marginally disabled with cerebral palsy.

Although the Balkans' Summer Music Camp is Nigel Osborne's personal initiative, he admits to acting on an assessment made by UNICEF, which diagnosed the children of Mostar as the most seriously damaged and least able to address the effect of violence and conflict in their lives. Music therapists and interns working at the Pavarotti Music Centre came to volunteer at the summer camp, as well as a group of therapists and teachers associated with War Child in Priština, Kosovo. About 15 university students from the Music Department of Edinburgh University came to

${ }^{1}$ Balkans' Summer Music Camp: 26 July to 2 August 2004 at Puntiežla/Pula, Croatia on the Adriatic Coast looking across at the Brijuni Archipelago. For further details see: www.ulysses.hr and www.warchild.org help, as well as half a dozen volunteers from Japan, Canada, England and Germany including myself.

Osborne had decided on Waiting for Godot for the opera project for a variety of reasons. Beckett's play seemed especially poignant for the children at the music camp, an ideal way of presenting creatively the painful truth concealed within, to which their hearts and minds bear witness. Exposed to the most inhumane brutality during the war, the children Nigel Osborne works with are 'real survivors'.

Since 2001 the Ulysses Theatre has run a cultural initiative of renewal on Brijuni Island, part of the Brijuni Archipelago, a protected National Park on the coast of Croatia. Three former Yugoslavs - actor Rade Šerbedžija, artistic director Lenka Udovički, and philosopher/ writer/translator Borislav Vujčić - decided to work with the cathartic effect of tragedy to implement social renewal and cultural regeneration in the aftermath of the war. Many of the best actors who fled the former Yugoslavia and received political asylum abroad have agreed to endorse this new initiative. Every summer a meaningful collaboration develops on Brijuni when the legendary figures of the past return to help forge new cultural terms for the future. The Ulysses Theatre aspires not only to capture aspects of brutal misfortune and psychological despair many suffered under the political regime in the former Yugoslavia, but often the intensity of interpretation portrayed on the stage subtly speaks of the recent atrocities witnessed during the war. Nigel Osborne was asked to join the Ulysses Theatre as music director and has set each feature to music. The first year Shakespeare's King Lear was produced in 2001, the second summer Euripides' Medea in 2002, Peter Weiss's Marat/Sade in 2003, and Samuel Beckett's Waiting for Godot in 2004. Osborne's contribution best reveals how compassion and inspiration can effectively transform music into a healing medium at a level of conscience.

Each summer the work from the previous years has been revived. As a result the Ulysses Theatre performed four plays in July and August 2004. Next year they are thinking of a new production of Othello in place of King Lear, which has been seen by 15,000 people during the past four summers. Besides the all-male production of Waiting for Godot in Croatian 'Play Beckett', the Ulysses Theatre hosted a workshop of an all female English cast with Amanda Plummer, Caroline John, Lynn Redgrave and Vanessa Redgrave (renowned for her initiative in human rights). The Ulysses Theatre usually performs on Mali Brijuni, in what was once an AustroHungarian fortress. The atmosphere of tragedy is 
enhanced by the permanent reminder of misplaced authority and power.

This year the Ulysses Theatre decided to make a film about the spiritual dimension of their work, for which they received permission for a workshop/production of Waiting for Godot on the island of Goli Otok, Tito's former penal colony for political 'deviants'. A few female survivors of Tito's concentration camp were approached to participate in the project and made themselves available for interview, giving testimonials of their suffering. The persecution of women on Goli Otok from 1949 to 1956 remains censored in the history of the former Yugoslavia. In an attempt to redeem the past through their workshop performance on Goli Otok, the all-English cast hoped to recapture the inhumanity of the female colony run by women. Waiting for Godot works as a double metaphor, not only representing the atrocities in the former Yugoslavia, but testifying to the recent injustices in our own flawed system, witnessed at Guantanamo Bay, Belmarsh Prison and Abu-Ghraib. I found it very meaningful to see Nigel Osborne's therapeutic work at the Balkans' Summer Music Camp set within a broader context of human rights issues that concerns us all.

Every morning the children swam in the sea, whereas afternoons were dedicated to drama and music workshops. Waiting for Godot was divided into seven short scenes for the children's opera project. The seven themes, which emerged from Beckett's text were: 1) putting on shoes, 2) waiting for something, 3) waiting for someone, 4) a tree, 5) a child/lullaby, 6) a dog and 7) a monster/giant. The children worked at finding words and music, as well as creating a short dramatic presentation to put their ideas across. What is often silenced in an individual who has been traumatized is given voice through music. The children experience through the opera project how their words and music are taken seriously by others. What often goes unnoticed and unexpressed in their inner lives, they perceive to be acknowledged and affirmed through hearing their words and music sung by others. The seven acts of the children's rendition of Waiting for Godot emerged as separate developments in the plot, but was linked by a common refrain composed by the different groups.

To help raise the aesthetic development of the opera within the consciousness of the children they went to perform their songs in a hospital in Rovinj, a neighbouring town. Although a medical centre for over 150 years, Martin Horvat Hospital is now being run during the summer months as a rehabilitation clinic for physically disabled children and adults, specifically addressing the needs of children who have been victims of land mines.
The director of the Martin Horvat medical centre in Rovinj made it clear that the beauty of the physical surroundings was the primary therapy people came for. At least 500 metres of sea front on the Adriatic has been redesigned for wheel chair access. People ordinarily unable to partake of a seaside vacation or swim in the sea can now experience the joy of a seaside holiday with an able-bodied friend or member of the family.

On the penultimate day of the music camp we were joined by the Mostar Sinfonietta, who play for the Ulysses Theatre during the summer. The Mostar Sinfonietta is unique insofar that it is comprised of musicians from different religious/ethnic groups in Bosnia Herzegovina. They joined the Balkans' Summer Music Camp to accompany the dress rehearsal and final performance of the children's opera. The melody and words of the songs in the opera project were composed by the children through a therapeutic dialogue with Nigel Osborne on his guitar, but their music was quickly orchestrated into parts by the composition students from Edinburgh University. Not only enriched by the support of the Mostar Sinfonietta, the children's production of Waiting for Godot was enhanced by the guest appearance of Vedran Smajlovič, the legendary cellist of Sarajevo. His musical contribution consisted of an improvisation on the cello depicting the monster, but a much more friendly creature than Beckett's Pozzo. Vedran Smajlovič's reputation in human rights emerged as he performed in Sarajevo wherever atrocities were perpetrated during the war. Surrounded by gunfire and snipers, he was often seen on the front line accompanied by his friend Nigel Osborne on the violin.

The children's audience was truly unique. Actors from the Ulysses Theatre as well as the female cast from England performing Waiting for Godot came to see the work of the children. It was wonderful to witness how the alchemy of music overcame all the cultural and linguistic barriers we had faced during our week together. The Balkans' Summer Music Camp renews one's trust in the human spirit to heal the unseen horror of violence and injustice in the world!

\section{Elizabeth Carmack}

The Balkans' Summer Music Camp is a charitable initiative run by Professor Nigel Osborne, Reid Professor of Music at Edinburgh. If you would like to make a donation to the Balkans' Summer Music Camp please send a cheque made payable to 'Edinburgh University' at: Music Department of Edinburgh University, School of Arts, Culture and Environment, Alison House, 12, Nicolson Square, Edinburgh EH8 9DF, U.K. 
London, South Bank and RAM: 'Omaggio: a Celebration of Luciano Berio'

The fortnight-long celebration Omaggio to the late Luciano Berio, held 15-30 April 2004, explored the post-modern passion and exuberance of the composer's musical personality, from the experimental daring and fun of the era of new music of the 1960s to the more searching multicultural tapestries of the final decades and his last works. Large audiences drawn from all ages enjoyed a wide range of Berio's works at the South Bank Centre and the Royal Academy of Music, including several UK premières including Stanze, his last work, as well as seminal pieces such as Sinfonia, Laborintus II, the fourteen Sequenzas, and electronic music, performed by leading virtuosi and ensembles. Overall, the festival represented a significant and memorable tribute to one of the leading figures of new music in the second half of the 20th century.

Just as last words are treasured and ploughed for every ounce of meaning, so also a composer's last works. Thus it was only to be expected that every note of Stanze, completed just weeks before Berio died in May 2003 and premièred in Paris on 22 January 2004, should attract great attention in its UK première, given by the outstanding baritone Francois Le Roux, London Voices and the Philharmonia Orchestra conducted by PierreAndre Valade at the RFH on 21 April 2004. Stanze came across as a compelling, expressive, thoughtprovoking work, significant within the development of Berio's late style, a final statement of depth and beauty. Sadly the RFH was far from full, symbolic of the difficulty in marketing new music, and the performance was not of the dramatic power and acoustic clarity one might have wished for. The problems of balance were possibly due to the unfamiliar distribution of the orchestra, to enhance the cluster effect of chords and blending of timbres brass separated on either side, woodwind and horns mixed up, and cellos and violins reversed. The result was that some of Berio's 'last thoughts', the vocal lines in this song cycle for baritone, triple men's choir and orchestra, were obscured by the instrumental forces, but this mattered little as the texts were printed in the programme.

Stanze is a cycle of five linked movements setting poems by different 20th-21st century poets, the title alluding not to 'stanzas' but to what Berio described as the true meaning of 'stanze', namely 'rooms that have doors and windows'. Each 'room' is inhabited by a contrasting poem, which evokes the 'unmentionable other and other place'. In an interesting programme note, Marco Uvietta describes Berio's work as a spiritual exploration of the idea of God in different situations, 'in Brendel's poem ironic, in Caproni, blasphemous, in Sanguineti, elusive, in Celan, a peremptory capital letter and in Dan Pagis, guilty'. Thus the work explores postmodern conceptions and perceptions of God. While that 'other' is sensed in the music through elusive sonorities and processes, nevertheless at the same time the work has an intriguing symmetry, dramatic bite and almost Classical formalism and teleology. The triple male choir sings in the second, third and final movements, while the soloist, here projected throughout with bright and incisive richness by Francois le Roux, appears ever-present, yet in each poem changing expressive character and emotional colour.

The first and last poems deal with Holocaust imagery, from the subject of suffering in 'Tenebrae' by Paul Celan, a poet quite frequently set by Berio and always in connection with the Holocaust, to the terror-filled silence of 'The Battle' by the Israeli poet Dan Pagis. Here the word 'schweigen' is artfully set to the dynamic climax of the whole cycle, a fortissimo chord which sustains and intensifies to a cry of Edvard Munchian proportions. The echoes between those framing poems are heightened by the use of a German translation of the Hebrew original, and by the use of rich harmonic textures in each. In the first, the lyrical and continuous vocal line is supported by dense clusters and rarefied blends of timbres sculpted into heaving waves that are grounded intermittently by the baritone's low pedal points at every mention of the word 'Herr' (Lord). By contrast the fifth takes flight in angelic floating sonorities, the voice enveloped by a halo of triple male chorus, dreamy and delicate, with celesta glissandi glittering through the high strings and wind chords. The harmony too is sweeter and more consonant than in the first poem, so that there is a sense of progression, even arrival, in the final movement.

The second and fourth poems are set to frenetic, busy textures, but while Giorgio Caproni's 'Congedo del viagiatore cerimonioso' (The Ceremonious Traveller's farewell) conveys a sense of relentless energy with its train imagery symbolic of death and Holocaust deportation, there is a more playful quality to the setting of Alfred Brendel's 'ironisch' Tritsch-Tratsch Polka poem. The main character in the Caproni bids 'farewell to knowledge to love and to religion' and the music, with choral echoing of individual syllables into ostinato patterns, is complemented by onomatopoeic low brass simulating braking 
engines. The soloist has an almost operatic tone here, while there is a more patter-song line to the fourth poem in Alfred Brendel's ironic verse. The song was apparently expanded from a sketched setting Berio gave to Brendel on his 70th birthday and there is considerable wit here in the fleeting allusions to waltz rhythms, while Strauss's famous polka makes an oblique appearance at the very end. The scherzo-esque effects of sonorities weaving in and out alters to a smoother texture at 'nothing must disturb the sense of harmony', and indeed such mirroring of text occurs throughout with great precision, which made the inaudibility of at least some of this performance particularly annoying.

At the heart of the piece is the central poem by Edoardo Sanguineti, a poet with whom Berio was closely involved, who wrote the text for Passagio and Laborintus II, and who shared Berio's ideas of multi-layered collage and quotation. According to Marco Uvietta, this is the most intense of the movements, but on this occasion, it seemed the weakest and most disparate. It is imbued with dramatic rhetorical gestures, with the choir adding sustained support to single vowels in the solo part. The fourth poem follows with explosive surprise, and not only balances the second as mentioned, but acts as a light relief before the visionary trance-like expression of the final poem. In the first poem, the sustained clusters are contrasted by two main points of activity: the first at the mention of 'It was blood that you shed, Lord' and the second for the image of 'Eyes and mouth are open and empty, Lord'. It is this line (with the assonance of 'Leer, Herr') which is echoed poignantly in the Pagis's 'The Battle', where the smooth harmonic cushion suddenly intensifies at "(the dead)...wide-open mouths silent'. Appropriately, it appears, the climax of Berio's final work embodies a struggle against the concept of silence and against the resistance to the articulation of suffering. The poignant fortissimo seems to defy Adorno's dictum that after Auschwitz there can be no poetry, as the poignant outburst at the final line, 'who knew who was cursed and who blessed in the burning dust' dies into to sonic embers and final silence.

If Berio's style is full of unpredictability so too is there an inevitability to the progression from impressionistic suffering to luminous transcendence, the spiritual journey of the work. In the words of David Osmond-Smith, the Berio authority and leader of a study day on the composer as part of Omaggio: 'His music refuses to forget'. Indeed the work is an eloquent public as well as personal testimony, expressed in Berio's distinctively exciting, imaginative and original voice, serious while engaging, light while meaningfully trivial, logical while sensuous.

Another highlight of Omaggio was the second UK performance of Berio's Ofanim, a stunning work composed in 1988, first performed in 1997 at the Barbican Centre with Berio himself in command. The work received an electrifying performance by the Israeli singer Esti Kenan Ofri, the New London Children's Choir, the London Sinfonietta and RAM Manson Ensemble conducted dynamically by Zsolt Nagy, at the QEH on 24 April, with the electronics provided by Berio's own Tempo Reale London-Florence project. Berio's interest in Hebrew texts dates from the 1950s, during his work with Cathy Berberian, his first wife, and continued with his tenure as conductor of the Israel Chamber Orchestra in the 1970s, his marriage to Talia Pecker, an Israeli musicologist who later became his librettist, and his teaching of leading Israeli composers such as Betty Olivero and Gil Shohat; amongst his many honours was the 1991 Jerusalem Wolf Foundation Prize.

The work contrasts settings of texts from the apocalyptic Book of Ezekiel and the passionate Songs of Songs. 'Ofanim' refers to the 'wheels' of Ezekiel's famous vision, conveyed by rich choral textures and loud percussion, contrasted by delicately sensuous sounds for the Song of Songs and instrumental interludes, such as a lively trombone duet, enhanced by spatial live electronics. At the riveting climax, the solo singerdancer emerges from the dark stage and gradually stretches to full height while gradually forming meaningful words out of raw syllabic sounds, in a manner recalling the experimental music Berio composed in the 1950s for Berberian, and which we later heard in the electronic music concert. Stretching short syllables into lyrical phrases over a static trombone note, Esti Ofri gave a magnetic characterization of the uprooted Mother figure, whose moving lament symbolized for Berio 'all the exiles ...that have left deep wounds in our conscience'. The daring spirit of new music in the 1960s was revived in the virtuoso account of Laborintus II (Homage to Dante) which concluded the concert. A classic from 1965, Sanguineti's text combines Dante fragments with his own jazzy post-modern prose poetry, and while the poet's son was to have been narrator, due to his indisposition Terry Edwards (one of the original interpreters of Berio's music) took over at short notice, reciting it in English, with the occasional Italian phrase. This enhanced the wit and mood, but perhaps missed something of the Italian sound colours. With the two ensembles, jazz bands, reminiscent of the 1960s Modern Jazz 
Quartet and other 60s jazz groups, the variety of vocal inflections and the way the ensemble builds textures of varying complexity and dramatic impact were thrilling; nearly 40 years after its composition, the piece is still as contemporary as ever.

The hardy souls who stayed for the late-night concert were rewarded with a spectacular performance of Sequenza XII (1995) for solo bassoon performed by its dedicatee Pascal Gallois. All the Sequenzas were performed during the course of the festival, showing the extremes of virtuosity Berio strove for. Rumour has it that since Gallois could play Berio's initial draft, it was rewritten to be even more impossible. Indeed the demands are phenomenal and it takes a phenomenal player such as Gallois to realise it, and on this occasion with magical artistry. At its simplest the piece is a single falling and rising glissando in a breath lasting 25 minutes. Using incredible variety of lip and breath pressure, and half-closing holes, Gallois achieved an effortless sense of tonal beauty, adding in the melismatic ornaments along with all sorts of multiphonics, undertones, flutter tonguing, extremes of dynamics and filigree, and all sorts of similar effects. Emerging from darkness onto a twilit stage, he made the work happen through an amazing 25 minutes of circular breathing: a fine tribute to the composer and the instrument.

Berio's own idea of programming his piano works together with sonatas by Scarlatti made the impressive piano recital by Andrea Luchesini on 26 April, Duke's Hall, RAM, into a type of première, a post-modern symbiosis of Baroque and contemporary idioms similar to Rendering, only here the focus was on Berio himself. Berio's music for piano is of the most compelling nature, concerned with harmony, texture and nuance. Sequenza IV (1966), the most extended of the works performed, was played effortlessly, with enthralling colours, subtle pedalling, overtones, and outbursts of activity, fast filigree reminiscent of - yet sweeter than - Boulez, hand-crossing, stretching to extremes of registers, sustained and silent chords. After Scarlatti's brightly dotted Sonata in D, Kk 491, came Brin and Leaf, miniatures in memory of the pianist Michel Oudor and London Sinfonietta manager Michael Vyner. These were concerned with a single chord expressed in different surface textures, sketch-like in the manner of a Haiku: hushed, condensed expressionism. Especially involving were Berio's four impressionistic 'Encores'. In Erdenklavier sustained notes and pedals create a pointillist pattern with emphatic tones, while Wasserklavier

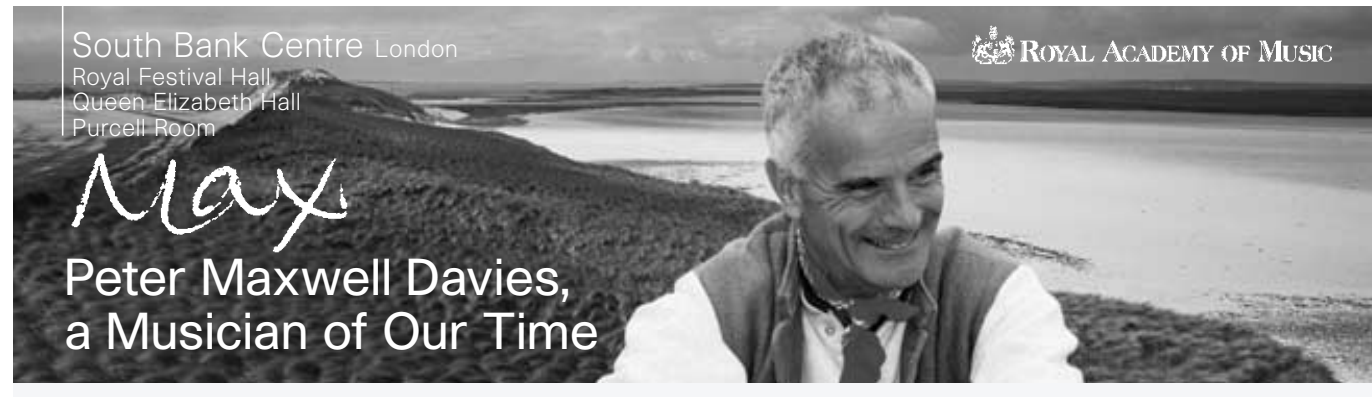

17 - 30 April 2005

Come to the South Bank Centre to celebrate a unique figure in British musical life. This festival brings together leading orchestras, ensembles and soloists, students and schoolchildren. Peter Maxwell Davies himself conducts, takes part in a masterclass and gives the Royal Philharmonic Society's Annual Lecture. Fourteen concerts showcase works from throughout his career, including world premieres of $A$ Dance on the Hill and Naxos Quartet No.6.

\section{www.rfh.org.uk/max \\ Box office 08703800400 \\ Brochure request line 02079210971}


Featuring:

London Sinfonietta
Philharmonia Orchestra
Psappha
Maggini Quartet
Endymion
City of London Sinfonia
Royal Academy of Music
Purcell Contemporary Ensemble
Westminster Cathedral Choir
Diego Masson
Oliver Knussen
Richard Hickox
Nicholas Kok
Jane Manning
Håkan Hardenberger


is more tonal, shades of late Brahms, yet vivid in its novelty, with the low concluding tonic leading evocatively into Scarlatti's F minor sonata Kk 239. The Debussyesque Luftklavier (1985) was followed by a riveting account of Feuerklavier with its toccata-like rhythms. A fast Scarlatti sonata in G Kk146, formed a bridge to Berio's powerfully explosive Rounds (1965) to conclude. Andrea Luchesini, a Beethoven as well as a Berio specialist (he has recorded Berio's concerto and performed Berio's 2001 Sonata the following day), was in brilliant form, his even tone beautifully lucid and glowing throughout. There was barely a breath between the Berio and Scarlatti which, smoothing the leap from 18th to 20th centuries with an intriguing similarity of colour, wove the music into a seamless whole.

It was apt that the two final UK premières of orchestral miniatures from the 1980s, should feature in a student concert, Fanfare for Berio, at the RAM's Duke's Hall on 30 April, with the RAM SO conducted by Pierre-Andre Valade, an event that symbolized the appeal of Berio for the future generations of musicians. In Fanfara, (1981), a short movement from the opera La vera storia, a woodwind harmonic strand is overlaid with brass motifs, while in Festum, commissioned for the Dallas SO in 1989, a percussion ostinato supports a brass polyphony gradually joined by strings, and concludes, after apparently fading out, with a sudden shockwave. Amongst four student pieces inspired by Berio, it was the Fanfare for Berio by Naomi Pinnock which most pithily captured Berio's wit and exuberance, and the concert, and festival as a whole, concluded with an impressively professional interpretation of Formazioni, Berio's orchestral tour de force from the late 1980s. Just as it was the searching musical response to the contemporary world of art and politics that marked out Berio's supremely musical achievement, so Omaggio's deeper significance emerged as a call to musicians to perform, listen to and discuss Berio's music, and to communicate and reinterpret Berio's ideals of experimentalism and his imaginative exploration of language and sound for our own and succeeding generations.

Malcolm Miller

\section{Presteigne Festival 2004}

The Presteigne Festival in the 21st century is in many ways the natural successor to the post-war years of the Cheltenham Festival, not just in its enlightened choice of first-rate contemporary
British music, but in its cultivation of house composers' who can be spotted browsing in local shops as well as providing the focus of several informal pre-concert talks. In fact, the music of three composers who received their first big commissions from the Cheltenham Festival William Mathias, Alun Hoddinott and John McCabe - were all celebrated at the 2004 Presteigne Festival.

Of the world premières on offer, James Francis Brown's Piano Quartet balanced florid writing of Tippett-like ebullience and energy with a more sombre and reflective central section. Far from outstaying its welcome, the piece contained enough material to merit further development and exploration. The Fidelio Piano Quartet's playing encompassed great refinement as well as robust attack.

Cecilia McDowall's String Quartet No 1, subtitled 'the case of the unanswered wire', was inspired by a Douglas Dunn verse novel describing the life of a Russian engineer on board ship during the 1905 Russo-Japanese War. Its bold, rhythmic drive was reminiscent of the Bartókian protean energy of Elizabeth Maconchy's quartets, whilst the moving final bars, dying away to nothing, made a delicately poignant ending to an intensely personal work that betrayed an acutely responsive creative sensibility. I hope McDowall will return to this medium again soon, preferably in the company of the Sorrel Quartet, who seem perfectly attuned to her musical personality.

The premiere of John Pickard's Orion for trumpet and organ also made a strong impression. The opening movement, entitled 'Nebula', established an appropriately otherworldly ambience punctuated by brief, ghostly fanfares. If this conjured up associations with the slow movement of Vaughan Williams's Sixth Symphony, the use of a flügelhorn in the central slow movement, entitled 'Alnitak', brought to mind the archaic weirdness of RVW's Ninth. In the Finale, 'Betelgeuse', the organist literally pulled out all the stops, but it was the return of the atmospheric opening material with the trumpeter offstage and eventually fading into the outer limits that lingered in the memory, for all the preceding pyrotechnics. It is hard to imagine anyone giving this music a more committed and virtuosic reading than trumpeter Alison Balsom and organist Jonathan Scott.

Among other high spots, Gemma Rosefield of the Fidelio Piano Quartet tapped into the full gamut of emotions underlying Judith Weir's small-scale masterpiece Unlocked in a deeply-felt rendering, but the gem among all the 24 events of 
the 2004 Presteigne Festival was a morning chamber concert featuring Catriona Scott on clarinet, accompanied by pianist Catherine Milledge. The very sight of the names Judith Weir, John McCabe, Alun Hoddinott and Matthew Taylor next to each other on the programme was cause enough for rejoicing, and the performances fulfilled the promise of such wise planning. McCabe's early Three Pieces and Hoddinott's Sonata from 1967 gave a timely reminder of the solid craftsmanship and sheer delight in music-making shared by these fine composers, whilst Taylor's witty Three Humoresques provided a genuinely apt precursor to Poulenc's autumnal sonata.

Unfortunately, not all the programming lived up to this level of sensitivity. Cecilia McDowall's String Quartet fared the worst, sandwiched without a break - between Mozart's Dissonance and Debussy's $G$ minor. It had fallen victim to a clumsy accommodation of the two 'themes' running through the festival, of French music and the chamber works of Mozart and Beethoven. McDowall must have been squirming in her pew to see her new work trapped in the middle of this exhausting, overstuffed marathon of a concert, carelessly thrown together. Ironically the postwar Cheltenham Festival was also guilty of this type of incongruous programming, where a new symphony by a promising young British composer would share the platform with Beethoven's Fifth, thereby prompting unhelpful and inevitably unflattering comparisons. By the early 1960s, the Cheltenham Festival board realized their mistake and began scheduling contemporary works which illuminated rather than eclipsed their new commissions. It's a lesson from history the Presteigne Festival would do well to heed before drowning any future commissions in extraneous mainstream repertoire. Presteigne doesn't need 'themes' (nor can it do anything but pay lip service to them in a mere six days). I hope it will concentrate on and continue to develop what it does uniquely and incomparably well - showcasing the best of contemporary and 20th-century British music.

Paul Conway

\section{Proms 2004: Adams, Corigliano, Saariaho}

Like its predecessors Nixon in China and The Death of Klinghoffer, the third opera in John Adams's trilogy, Doctor Atomic, seems set fair to juxtapose modern political forces, personalities and moral debate. Here admiration for Robert
Oppenheimer and his fellow geniuses who created the atomic bomb is contrasted with the enormity of destruction wreaked on Hiroshima. With over a year to go to the opera's world première by San Francisco Opera, the composer himself conducted Easter Eve 1945, the opening of Act 2, at the Albert Hall on 22 August with the BBC Symphony Orchestra and Audra McDonald as soloist.

Kitty Oppenheimer, Robert's wife, sings an aria that, after its opening premonition of the moment of detonation, is a reflective and restrained setting of Muriel Rukeyser's poem of the same title. Kitty, as Adams portrays her, is the 'moral conscience' of the opera, the thoughtful one in contrast to the 'Yankee ingenuity and optimism' of the breakthrough-hungry scientists in Adams's characterization.

Brash, harsh stridency vs. slow free-floating rumination are the twin poles around which the earlier operas revolve. Easter Eve's wordiness, and Adams's decision to set such an abstract, intellectual poem, also remind us of his love of complex female 20th-century poets - witness El Niño. This latest piece also foregrounds a text that is essentially undramatic. 'Now I say there are new meanings now I name/Death our black honor and feast of possibility' are typical lines. Adams is stronger on foreboding - from the eerie string-inflected midnight atmosphere to the aria's highpoints: solos for trumpet and horn, the latter recalling Britten's own 1945 Serenade.

Born in Massachusetts, Adams has been a resident of California for over 30 years. His new concerto for electric violin, The Dharma at Big Sur, given its European première in the same concert with Tracy Silverman as soloist, moves us from the University of California's research facility at Los Alamos to the 'super-real' (Adams's description) beauty of the echt-Californian Big Sur with its plunging coastal scenery. The concerto draws on the state's radical side: Kerouac travelling there in the 1960s, Jimi Hendrix at the Monterey rock festival in '67, the Indian-influenced hippie culture (not to mention Terry Riley and Lou Harrison). The solo part draws upon all these traditions, from druggy meandering, to passages that sound like improvisation, to Hendrix-like (Silverman even leaning back as he plays) high-register intensity. The first movement, 'A new day', states its rebirth notions by using not only an orchestra (minus most woodwind) that is re-tuned using just intonation, but also clear, uncluttered harmonies and textures providing a slow background against which the soloist emerges, the amplification exploited so that the apparent lack of attack 
makes the violin sound like some primitive pipe. This is the new day of Matisse's 'Music' or the old, sure religious harmonies of Adams's own Common Tones in Simple Time (1979).

The solo violin plays almost continuously, with modest orchestral support - including two samplers - using material derived from a simple rising and falling three-note figure played portamento. There is both a tranquillity and obsessiveness in the violin part that lends itself naturally to a jazz-inflected style. The problem is lack of tension. The movement, slow throughout, has a brief coda where tuned metal percussion bring that familiar California freewayglittering-in-the-sun feel that we know from Adams passim. But piling Eastern mysticism, jazz, even the bright new dawn of proto-minimalism in the mid-60s all together gives us a surfeit of laidbackness. The lack of rhythmic drive is made up for in the second movement, which starts attaca, the soloist pressing the orchestra forward with a snappy repeated figure that gains in length and expressive power by transforming the first movement's principal phrase. Double-stopping is used almost for the first time, and as the soloist soars off onto a fff climax the music is driven along by percussion again until we are momentarily back in familiar American raptures. Everything only really comes together in the second half: the electronically-echoing violin sounds like an ecstatic sitar, the ever-quickening and more complex solo part - using material previously dwelt on languorously - becomes infused with drive and momentum in a confident, hammering orchestral texture. East and West are triumphantly united.

Although he is about 10 years older than Adams, John Corigliano's reputation has not risen so rapidly in his native America or in Britain. The performance of his 1977 Clarinet Concerto on 1 September by Michael Collins and the BBC SO, this time under Leonard Slatkin, was not only its first performance in London, but the first time that any of his music has been played at the Proms.

In a pre-Prom interview, the London Times' John Allison put it to the composer that 'eclecticism' was much in evidence in his work, and that this approach had attracted some criticism. Corigliano parried by saying that 'I write in lots of different styles' - as indeed he does, but what Allison appeared to be euphemistically wondering was how derivative of other composers Corigliano is. (The recent Second Symphony has many strengths, but much indebtedness too.) The Clarinet Concerto, one of Corigliano's most popular works, is an interesting case in point. The bright, extravert opening movement sounds like no-one else in particular and embodies the qualities that can be found in his music since the 1970s. 'I wish to be understood ... communication should always be the primary goal', he has said. Indeed, the first movement communicates effectively in a number of ways. First, the solo part is showy and impressively difficult-sounding, but the central feature of the two cadenzas that make up the movement are very fast up-and-down quaver runs that are as exciting as they are easy to spot when they recur, or when orchestral soloists take up and build on these elements. Second, and helping the audience to maintain its grasp of the work, even at first hearing, is the structure. The opening cadenza 'Ignis fatuus' bursts with free-running energy which colours the interesting central 'Interludium' before the final cadenza, 'Corona solis' (strange that such a populist as Corigliano should go for Latin titles), bursts back in with material - runs, trills and loud, dramatic leaps derived from the first. Third, with its percussive pianos, drums and exuberant solos for orchestral soloists too, the work has many of the qualities of its original conductor and dedicatee Leonard Bernstein. (Bernstein would doubtless have added some vernacular or jazz-type rhythms to a Clarinet Concerto of his own; Corigliano's piece is notably more parsimonious with such eclectic borrowings as well as changes of mood.)

The slow central movement, an elegy for Corigliano's father, concertmaster of the NYPO for 23 years, doesn't dispel the concern that the work communicates fluently but not profoundly. It heavily features the strings, opening with unaccompanied, slow, desolate textures and a soulful melody that the soloist later joins with one of similar character. The mood is unvaried throughout, seven minutes or so deliberately written, so Corigliano tells us 'without an emotional climax'. This is original in an elegy but not very satisfying; nor in truth is the movement elegiac, there being no shifts of emotional gear, no stabs of grief, no memories of happiness, just a slow lament. At letter ' $\mathrm{N}$ ' a solo violin unexpectedly joins the texture rather than the clarinet, which is a touching and effective surprise, but it is not quite enough.

The fast finale, 'Antiphonal toccata', is thrilling. Corigliano throws in numerous elements: irregular rhythmic pulsations, the slow processional of Giovanni Gabrieli's Sonata pian' e forte, two timpanists with some cracking figures duetting left and right, a brass cluster-chorus operating at an independent tempo from the rest of the orchestra and, as if this weren't enough, off-stage (actually in-audience) groups of brass 
and clarinets that take up the soloist's 'computerlike' fast-toccata figuration and exuberant runs. The full brass Gabrieli comes blazing in (cf. Britten's Young Person's Guide) and all the various excitements bubble frantically in the same pot at the end. This is the triumph of eclecticism. Noone is going to object to the use of the Gabrieli quotation, even if the finale's impact is so heavily dependent on it. Drama - yes, communicability certainly, but in the flurry of messages, what finally is being said?

No such audience-appealing concerns perturb Kaija Saariaho. In yet another Prom in quick succession by the BBC SO - on 7 September, this time under Jukka-Pekka Saraste - her 2002 orchestral piece Orion was given its UK première. Asked by Tom Service whether scores like this one displayed, in their clarity, a heightened interest to communicate, Saariaho ruminated and answered in the negative.

Whatever her intention was, Orion is a more approachable work than the two well-known linked 1990 pieces for orchestra Du cristal and ... $\dot{a}$ la fumée, recently reissued in performances by the Los Angeles PO under Salonen on Ondine. The CD's addition is the interesting but hardly butterfly-like Sept papillons (2000) expressively played by Anssi Karttunen. Not only is this her longest purely orchestral piece at 25 minutes, but the three descriptively-titled movements show Saariaho, avowedly a non-programmatic composer, come rather closer to the actions of human beings, albeit mythical ones, than previously.

Orion is the name both of a constellation and of the murdered son of Neptune, and to this duality Saariaho has added the life/death dichotomy of the first movement 'Memento mori'. The movement is particularly successful as Saariaho is more seductive and less gritty in her sound-world than we are used to. A subtle lament of anguish using glissando flutes during the funeral procession-like section with its primitive descending figures manages to be formally distant and energetic yet at the same time personal and lamenting. Better than - in territory they both inhabit - Birtwistle.

The second movement, 'Winter sky', is more static and impersonal and shows Saariaho's mastery of highly-coloured 'spectralist' orchestral writing, but the movement manages to be more interestingly melodic than usual for this school, even within its typically glacial atmosphere. A sky full of winds and birds as well as glistening stars. It is less certain how well Saariaho can do happiness. The last movement, 'Hunter', is marked sempre giocoso, yet Saariaho's loud woodwind scales and brass mottos sound like a cross between Messiaen and, oddly, John Adams. It's all rather too earnest and thickly scored when an element of playfulness is surely what's required. Still, both the fast tempo and the role given to solo instruments are conscious departures for the composer; if compositions like Orion are the result of a new approach her name, without too much effort, will continue to rise higher in the musical firmament.

Robert Stein

\section{Proms 2004: Turnage, Bingham, Sheng, Silk Road, Henze}

In fulfillment of a commission from the BBC for a work in commemoration of the 75th anniversary of the BBC Symphony Chorus, Mark-Anthony Turnage produced Calmo, an untypically quiet and gentle work for chorus with handbells - and, what has become something of a signature instrument for him, desk bells. The text of the work consists of the words 'Dona nobis pacem' and their translations in several languages. It is dedicated to the memory of Turnage's friend Sue Knussen. Calmo's intense eloquence was enhanced by its brevity, and, both despite and because of it, stood out in a program of music for chorus, harp, and organ by an assortment of older and newer Czech and British Composers, including Janáček, MacMillan, Holst, and Eben, presented by the BBC Symphony Chorus, conducted by Stephen Jackson.

The concert ended with the first performance of The Secret Garden for chorus and organ, another BBC Commission, by Judith Bingham. Bingham is the librettist as well as the composer of the work; her text is a meditation that connects biblical quotations from Genesis (about the expulsion from Eden) and the Gospel of St. Matthew (about the Kingdom of Heaven). The choral writing of The Secret Garden is elaborate and effective. The work itself is somewhat prolix, and seems to dispose of the words of its text at an inexorably consistent rate. The most effective and successful part of it, for this listener, was the organ solo which is the work's fulcrum.

A greatly expanded London Sinfonietta, conducted by David Robertson, presented a concert consisting of the first UK performance of Bright Sheng's The Song and Dance of Tears and the Messiaen Turangalîla Symphony. The Sheng was originally commissioned by the New York Philharmonic to mark the anniversary of the debuts of Emanuel Ax and Yo-Yo Ma with the 
orchestra. Ma requested that the work be related to Sheng's travels along the route of the old Silk Road and that it include a pipa soloist. Eventually it was agreed that Sheng would write a quadruple concerto for the Western cello and piano and the Chinese pipa and sheng.

The three movements of the piece, entitled Song, Dance, and Tears, respectively, are pretty much as advertised. Sheng's fears of the pipa's not being able to be heard over an orchestra was the cause of his initial reluctance to include it in the work. In this performance the decision to amplify the pipa - or at least as it was done on this occasion - seemed like a miscalculation, since in fact most of the time it was balanced over the other solo instruments, none of which stood out as clearly against the rather thick orchestral mass. Balances in general could have been better: early on in the piece, solo instruments from the orchestra which seemed to be intended to play ensembles with the soloists were practically inaudible. The Song and Dance of Tears is dramatic, attractive, elegantly wrought, and compelling in much the same way that extremely good music for movies is; and, in the same manner as most movie music, has a fairly consistently low melodic profile, making it all seem a little unspecific. That quality was highlighted by comparison to the
Messiaen, which, however robust, rollicking, brawling, silly, and just downright tacky it may be from time to time, left no doubt, even in this rather overly polite and refined performance, about its intention, its earnestness, or its genuineness.

The Silk Road Ensemble, a crossover project of Yo-Yo Ma's, members of which were the soloists in the Sheng work, returned to the Albert Hall two days later on their own, playing music from an array of non-western music cultures. The program, which featured consistently beautiful playing, nonetheless raised questions and doubts about exactly what was going on, and what it all might mean. The program note informed us that the Mongolian composer/arranger of the first work and the fabulous singer in that work, a compatriot of his, both 'represent a new generation of urbanised Mongolians ... who are as comfortable in one of Ulaanbaatar's many discoteques and Internet cafés as in a ger, the round felt tent of Mongolian herders.' After the initial feeling that somebody might be pulling one's leg, one wondered just what to make of all the implications of that statement. A certain vertiginous quality was provided by performances of music of the Roma, featuring a solo by the pipa player in the manner of The Tiger

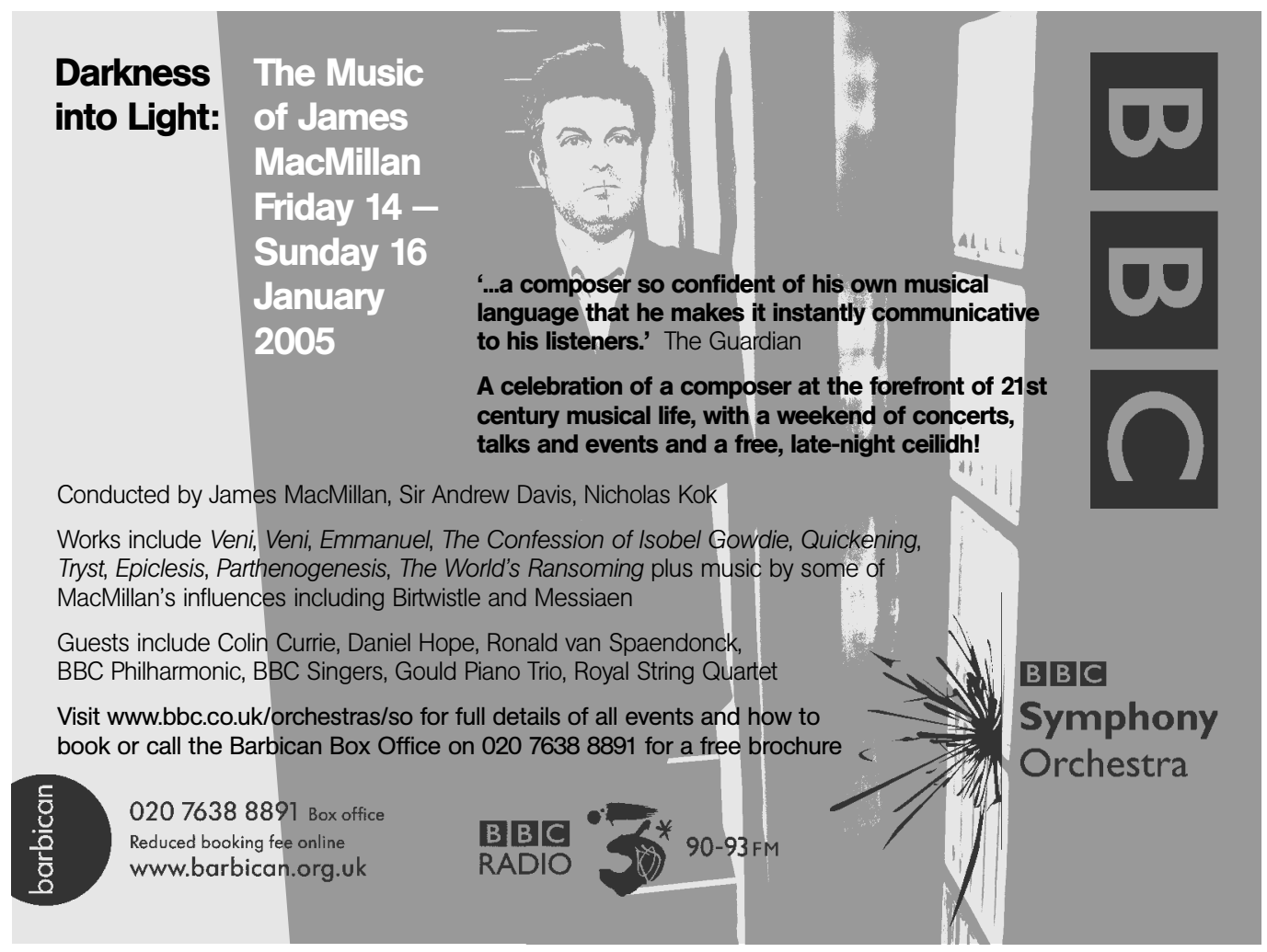


Rag. The program presented transcriptions, arrangements, and original works for ethnic instruments as more or less the same thing, without hinting that what was being performed was not exactly authentic folk music. Little acknowledgement was made of the fact that someone had had to write or arrange this music, or of those composers and arrangers, beyond their names and birth years. This listener found a certain self-congratulatory assumption that the Silk Road Ensemble was making the world a better place for us all to live in not particularly appealing. It may well, be, though that none of these reservations was important in the light of the spectacularly dazzling playing and the consistently infectious music making. Certainly the very large audience seemed to be having one whale of a time.

The Hamburg Philharmonic Orchestra and conductor Ingo Metzmacher brought the first UK performance of the Tenth Symphony of Hans Werner Henze to the Proms. Henze first imagined the music of the symphony to be 'something crystalline and clear and English', conveying the quality of its intended first conductor, Simon Rattle, as 'a modern man in love with the world'. Although each of its four movements has a romantically evocative title - A Storm, A Hymn, A Dance, A Dream - they are arranged in the manner of a classical symphony: a substantial first movement, a slow movement, a scherzo, and a reflective finale. Musically the work also has a highly evocative romantic quality. Henze deploys the enormous orchestra used in the symphony with consummate and magisterial mastery, unfolding at just about every moment of the work beautiful and breathtaking instrumental textures. Like the Sheng piece, however, the symphony has a lack of melodic character and profile which makes its effect more general than specific. The performance of this very difficult work - apart from the slow movement which seemed to be a little hurried and had a certain cursory quality was assured, understanding, and compelling.

Rodney Lister

\section{Proms 2004: Zhou, Casken, Hillborg, Vine, Talbot}

The Immortal by the Chinese-American Zhou Long (b. 1953) - commissioned by the BBC World Service (apparently its first-even Proms commission) and premièred by the $\mathrm{BBC}$ Symphony Orchestra under its out-going chief conductor, Leonard Slatkin, on 20 July - is a tribute 'to the influence of Chinese artists and intellectuals in the twentieth century', as the composer notes in the score. He adds: 'Having grown up in an artistic family during the time of the Cultural Revolution, I know from personal experience the struggles and hardships that past generations have endured to remain true to these eternal ideals'. Past generations? Zhou himself was sent to labour in the fields; a back injury had him re-allocated to a song-and-dance troupe, where he encountered notionally prohibited western instruments among the Chinese ones - a stylistic integration he maintains even when writing exclusively for the modern symphony orchestra.

The Immortal, 13 minutes long, opens with driving dissonances and the hint of Mossolovstyle machinery before a passage of eerie glissandi suggests not man but malevolent nature, with threatening string pizzicati and shrill bird-calls in the winds. The glissandi, Zhou notes, 'represent the desire for hope', but the music hints that this is the torture par l'espérance (Villiers de l'Isle-Adam) that Dallapiccola expressed in Il prigioniero. A few fragments of melody struggle to articulate themselves, but the glissandi - here are his western instruments suggesting Chinese originals - stir up brooding, increasingly violent tempers, silenced by a fff chord. The uneasy stasis which follows hints at the ritual gestures of traditional Chinese music, pentatonic snippets set into an atonal framework, the edgy melodic fragments cross-cut by those glissandi elsewhere in the orchestra. At last a driving march-rhythm gives the music focus and coherence, but it is soon silenced, and the orchestra shakes itself in a mighty spasm, quickly balmed by a passage of chimed stasis which defeats occasional attempts at motion. Quickening rhythms bring in another stamping gesture - tiny hints of Messiaen here and the music sinks down into uneasy silence.

Coincidentally, BIS has released a disc of four orchestral pieces by Zhou, which showcases his attempts to integrate oriental and occidental tradition before The Immortal (BIS-CD-1322). It opens with Poems from Tang (1995) for string quartet and orchestra: four movements, half-anhour long. The first, 'Hut Among the Bamboo', is all delicate half-shades, overheard gestures, high glissandi and harmonics perhaps suggesting an overhead bamboo canopy (the image occurred to me before I noticed the title). The second, 'Old Fisherman', effects an extraordinary marriage of Chinese sonorities and western instruments; for the first time something emerges that western ears would recognise as melody, and eventually the music surges forth in a wave of joy, which 
quickly subsides, leaving a shy optimism. 'Hearing the Monk Xun Play the Qin' (a zither) opens with distant chimes (inspired, apparently, by the sounds of bells across Lake Como) that are interrupted by a series of angry lashes; the orchestra boils with unfocussed anger and the bells close calmly in again. The closing 'Song of Eight Unruly Tipsy Poets' is Zhou's Sorcerer's Apprentice: good humour gradually losing control of ebullient energy which threatens to overwhelm its origin - and evidence that Zhou can throw an orchestra around as well as paint aquarelles. Further evidence comes with The Rhyme of Taigu (2003) which recreates the taigu drumming tradition of ancient China with a forceful vigour that makes this piece something of a cousin to Revueltas' Sensemayá, with the lusty enthusiasm of Copland's 'Hoe-Down' in its whooping closing pages - here's a piece that audiences would respond to very directly; and at twelve minutes long, it would make a perfect concert-opener. $\mathrm{Da} Q \mathrm{Q} u(1990-91)$ is a percussion concerto of sorts (soloist, the dazzling Jonathan Fox), far less western, more ritualised, than The Rhyme of Taigu - far less fun, indeed, though no less exciting when it builds up a head of steam. The stamping, off-beat chords in the first section bring The Rite of Spring very directly to mind; the finale heaves with energy but without an equivalent sense of purpose. The disc ends with the brief but powerful The Future of Fire (2001, rev. 2003), for choir and orchestra, based on a Shaanxi love song - another Sorcerer's Apprentice story of the farmers' fire running out of control, and sounding for all the world like a cross between Steve Reich and Borodin's 'Polovtsian Dances'. Not having any point of reference, I imagine the performances, by the Singapore Symphony Orchestra under Lan Shui, are excellent; and the sound is the usual BIS equilibrium of immediacy and transparency.

Back to the Proms, and to John Casken's Symphony, Broken Consort, a BBC commission given its world première by the $\mathrm{BBC}$ Philharmonic under Gianandrea Noseda on 22 July. Casken's programme note observes that 'A symphony is not only a large-scale orchestral work, but one that sets out to integrate contrasting material into one unified structure'; the title alludes to his inclusion of a 'gypsy' ensemble in the orchestra: cimbalom, piano accordion, electric violin and mandolin, grouped around the conductor for safety - another Eastmeets-West piece to satisfy one of this Proms season's half-cocked thematic conceits. Casken begins by playing sonorities and melodic lines against one another (why have so few other composers noticed how effectively the accordion slices through orchestral textures? It's a tremendously potent colouristic resource), and flickering whisps of energy gradually energise the music. But it takes the 'gypsies' 13 minutes - far too long - to stir the westerners into a wild dance which, after all that waiting, fizzles out far too soon and the piece drifts listlessly onwards; a surge of power briefly looms and disappears into the murk. The first movement was met by applause: not uncontrolled enthusiasm but gratitude from the audience who thought it was over and who didn't find enough point of contact between Casken's programme note and the music itself to work out where they were. The second movement began the directionless weft as before; another irruption of energy gave hope that something genuinely symphonic might emerge - but no, and the play of static sonorities resumed. The gypsy dance breaks out again, sending the orchestra spinning into a fierce scherzo that slowly runs out of steam and coasts into silence. Broken Consort didn't begin to justify its 35-minute duration: the contrasts weren't stark enough, the material not memorable enough for the thematic integration to tell as a structural device. I wonder whether some drastic surgery might turn this treatise in texture, with its occasionally kaleidoscopic play of colour, into something that packs more of a punch; I'm not at all sure it would.

One of the more satisfying newcomers at this year's Proms was the Swede Anders Hillborg's Exquisite Corpse (2002, revised the following year), given its UK premiere by some visiting compatriots, the Royal Stockholm Philharmonic Orchestra under their young American chief conductor, Alan Gilbert, on 5 August. The title, as Guy Rickards's note explained, is derived from 'a curious parlour game played by 1920s Surrealists, in which a prose text or poem was collectively created by various participants, each contributing a word in turn but concealing it from the others until the end-point was reached and the finished work read out' - more familiar (minus the grammatical rules) to contemporary listeners as 'Cheddar Gorge' on that emperor of all radio programmes, I'm Sorry, I Don't Have a Clue. Hillborg reflects this procedure in a 17-minute orchestral fantasia, doubling as a concerto for large orchestra, concatenating episodes containing references - sometimes quotations, sometimes stylistic allusions - to Stravinsky (Petrushka), Ligeti and other composers who have meant something to him, concluding with a radiant quotation from Sibelius's Seventh Symphony that introduces the lyrical closing 
pages. In the event, Exquisite Corpse was surprisingly unepisodic, each section flowing smoothly into the next; Hillborg's easy alteration of fuller scoring and chamber-music textures regularly refreshes the ear and - behind the pullulating surface details, shifting like the surface of the sea - his harmonies suffuse the work with a heart-warming inner glow. Exquisite Corpse is one of the most sheerly attractive new works I have heard in a while: always interesting, sometimes even beautiful. The adjective in the title is fully justified.

Another group of visitors, the impressively disciplined Australian Youth Orchestra under Lawrence Foster, brought us the UK première of Carl Vine's brief (six-minute) Celebrare celeberimme on 30 August. Scored for a full orchestra, it's a good-natured toccata that shakes itself awake with delicate tendrils of melody which pass around the orchestra as a sunny, summery pastorale gently emerges. After a broad tune the tempo gradually picks up, the orchestra generating speed and strength, the brass intoning a theme that wouldn't be out of place in an American film-score. Sideand bass-drums batter out a tattoo, the temperature cools, and a brief Goodwinesque apotheosis rounds the piece off à la 633 Squadron (not a pejorative comment, by the way: 633 Squadron contains some of the most memorable orchestral writing you can hope to hear).

Celebrare celeberimme did what it was intended to do: allow the orchestra a swift and jolly flourish before it settled to meatier fare. Joby Talbot's 13minute Sneaker Wave - another BBC commission, receiving its world premiere on 2 September from the BBC National Orchestra of Wales under Grant Llewellyn - overstayed its welcome. Likewise an orchestral toccata, it begins with bubbling overlaid patterns, announcing its minimalist credentials from the start. Happy and consonant, it is dominated by bright, open colours only occasionally disturbed by a 'sneaker wave' (a rogue wave which can surprise surfers) welling up within the orchestra; the scoring with prominent tubular bells, marimba, xylophone, marimba, harp and piano - reinforces the buoyant mood. And so the piece proceeds on its merry way, its displaced rhythms unfazed by the odd dark shadow. By the time it reached its brass-capped climax, reinforced by a supererogatory organ, we had more than got the point: the brusque ending was five minutes too late. The essence, surely, of a sneaker wave is that you don't foresee what's coming; unlike Hillborg's, the adjectival part of Talbot's title was a misnomer.

Martin Anderson

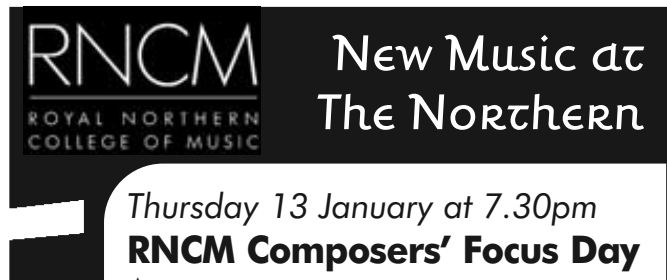

A unique opportunity to see a selection of compositions by RNCM students - rehearsed and recorded throughout the day - performed in public.

Thursday 20 January at 7.30pm

\section{The Kronos Quartet}

Appearing at only three venues during a brief UK tour, one of the most celebrated and influential ensembles in the world today perform at The Norzh $\in$ Rn.

The programme includes a Meredith Monk world premiere, plus works by Kevin Volan, Michael Gordon and Franghiz Ali-Zadeh.

\section{Saturday 29 January at 7.30pm Birmingham Contemporary Music Group}

\section{Songs and Dialogues}

Conductor

Oliver Knussen

Mezzo Soprano Mary King

Piano

Nicholas Hodges

Live electronics

Jonty Harrison

and

Lamberto Coccioli

The songs are Stravinsky's - gems from across almost half a century of his composing life - the dialogues are Elliott Carter - mature music praised by Stravinsky. Two comparative youngsters - Andriessen and Anderson - complete the programme.

For further information or to book tickets, contact the RNCM Box Office on 01619075555. Royal Northern College of Music, 124 Oxford Road, Manchester M13 9RD. Email: box.office@rncm.cc.uk www.rncm.ac.uk 
Gloucester Cathedral: Variations on 'Down Ampney'

Commissioned by the Three Choirs Festival and performed there for the first time on 13 August by the Philharmonia Orchestra under Martyn Brabbins, these variations on Vaughan Williams's hymn tune 'Down Ampney' (so named after the village of the composer's birth), were surprising individual successes. The overall shape of the work, arch-like with a slow-fast-slow-fast-slow structure, was suggested by John McCabe, celebrating his 65 th birthday year and featured composer at this year's Three Choirs. McCabe, joined in this collaborative effort by Robert Saxton, James Francis Brown, David Matthews and Judith Bingham, also sensibly requested that the orchestration be limited to double woodwind, modest brass and percussion sections, harp and the usual strings.

The work opened with McCabe's orchestration of the theme, beautifully set in the woodwind and horns with a gentle nod to Vaughan Williams's own Fantasia on a theme of Thomas Tallis in the opening paragraph. This led seamlessly into McCabe's own variation, in compound time, again with filigree writing in the woodwind, and with duplet punctuation in a quartet and later an octet of solo violins. The theme was to be found in a brass chorale interspersed with beautiful woodwind colouration.

The quicksilver dash of Robert Saxton's compact second variation was sadly lost in the Gloucester Cathedral acoustic, but a driving rhythmic thrust in the string writing was evident; Saxton made use of constantly changing orchestral colour between woodwind, horns and brass and culminated in an impressive fff climax.

James Francis Brown's central slow movement, a delightful lightly-scored confection, was possibly the most successful at utilizing the special acoustic properties of the cathedral; Brown's music has the spirit of the English renaissance, and his striking facility as a composer was evident from the very first bar.

Next followed an impressive scherzo from David Matthews; here we heard the work of a master orchestrator who served influential apprentice periods with both Britten and Tippett. How exciting, vivid and self-assured this variation was - but again, despite an excellent performance from the Philharmonia, much of the detail was absorbed by the cathedral acoustic.

Finally a mesmeric, almost minimalist variation, entitled The Yearning Strong, from Judith Bingham. Here gentle pizzicato figures in the strings and glimpsed memories of the 'Down
Ampney' theme in the woodwind were accompanied by a simple quaver pattern played on sandpaper blocks, a most effective resonance. This gently beautiful variation brought the work to a quiet but satisfying close.

I would love to hear these variations again in a drier acoustic, and they stand up well as individual pieces; unfortunately, however, the whole, on this occasion, was not greater than the sum of its parts. The variations are published by Maecenas Music.

George Vass

\section{London, Temple Church and Cheltenham, Pittville Pump Room: Wood's 'Cantilena and Fugue' and 'Tribute to Michael Berkeley'.}

It has been three years since the last Hugh Wood première (his Fifth String Quartet), and in that time his music has disgracefully become an endangered species - practically extinct - in concert programmes. Therefore, his Cantilena and Fugue op. 47, given its first performance on 7 July as part of the City of London Festival, was doubly welcome. And, as if to compensate for the wait, a second new work followed just two days later, with the première of Wood's Tribute to Michael Berkeley, one of 20 short works commissioned to mark Berkeley's final year as artistic director of the Cheltenham Festival.

The Cantilena and Fugue, for the unusual combination of trumpet and organ, opens with a broad, expressive melody for solo trumpet. Varied repetitions of this tune in both the organ and trumpet underpin much of what follows, sometimes prominent, at other times functioning discreetly as a cantus firmus. The emphasis is thus on the melodic material (and, as is to be expected with Wood, on motivic concentration) rather than colour; the careful selection of organ stops nevertheless cleverly articulates thematic material and structure.

The subsequent Fugue, which Wood marks 'Brisk, brash', complements the Cantilena delightfully. Where the latter is sustained and song-like, the former is characterised by staccato, detaché quavers vigorously arpeggiating up and down through leaps of (mainly) fifths. Despite the brevity of the movement, Wood finds time to present the subject in all manner of inversions, augmentations and strettos, before stopping the fugue in its tracks to end with a buoyant coda.

The Tribute to Michael Berkeley, for solo viola, represents Wood at his most romantic and eloquent, opening with arcing melodic lines and growing to passionate and lyrical declamations, 
before returning to the opening calm at the end of the work. A moving quotation towards the conclusion of the opening three chords from Beethoven's Sonata op. 81a ('Das Lebewohl'), makes for a fitting farewell to Berkeley, whose tenure at the Cheltenham Festival has resulted in many of the recent performances of Wood's music.

Given the relative lack of opportunity to hear Wood's music, it is critical that performers get it right. In the case of the Cantilena and Fugue, I regret to say that many in the audience would have been left with a less than satisfactory impression of the work due to many small but significant pitch and rhythm slips from the trumpeter Deborah Calland. Full marks though to Roger Tapping, whose compelling performance of the Tribute revealed to the audience just how powerful and expressive Wood's music can be.

Edward Venn

\section{London, Purcell Room: New French Song}

'I haven't heard my piece yet, none of us have', confided thirtysomething composer Will Todd as he arrived to take his place in the audience at the Purcell Room on 13 July. He spoke as one of the twenty British composers, all alive and well, commissioned by artists Alison Smart (soprano) and Katharine Durran (piano) to set a French poem for them to perform. Unusually, the composers had to submit their scores as if 'tablets from on high', without rehearsal input. Although this worked well as they all entered into the spirit, and the artists seemed particularly adept at interpretation over a wide range of genres - from Graham Fitkin's mimimalist-style 'Les Aliments Blancs' (Satie: 'je ne mange que des aliments blancs'), to John Casken's impressionistic 'Colloque Sentimental', with its shades of Debussy - having such a swift succession of 20 short 'soundbites' made for a rather over intense programme overall. Perhaps, on another occasion, a concentration on no more than ten composers, would allow for rehearsal time with each to assist in conveying more in-depth interpretation of the text, and give the audience more time to absorb each contribution.

The galaxy of composers, all distinguished in their own field, produced a highly accessible range of songs, based on poems from Hugo to Prévert. There were several settings of Stephane Mallarmé, notably Nicola Lefanu's imaginative treatment of 'Billet à Whistler', with its astounding opening virtuosic burst of energy, and angular leaps of vocal line throughout, interspersed with use of spoken monotone in low register. Standing out as one of the most innovative scores of the evening was Sadie Harrison's amazing use of varied font sizes for an exposé of text of Mallarmé's '... issu stellaire', combining the visual impact of the page set of the words with corresponding 'clusters' of sound. As Sadie herself describes it: 'My setting of extracts from Un coup de dés, attempts to capture something of Mallarmé's "empire of passion and dreams", where silence is as important as sound, where images are strewn like stars on the page'. Her portrayal of individual lone stars, in the heavenly constellations, is punctuated by silences, most ominously.

Most impressive of all, in innovative terms, was Adam Gorb's 'La Cloche Felée', setting a poignant poem by Charles Baudelaire, where the cracked church bell was denoted by the pianist cleverly 'stopping' the bass strings of the piano to produce a dead rasping sound, 'like the heavy death rattle of a wounded man'.

Of course in setting French poems, there is a tendency to the over-staid or stilted idiom, whether in the original score, or in manner of performance, but Howard Skempton managed to avoid this in his setting of Apollinaire's 'Le Pont Mirabeau'. Will Todd, whose swiftness in establishing himself as one of Britain's most promising young composers I have previously charted for Tempo, went even further in his setting of the same text, which, in true Todd style, gripped the audience with the sheer flow and passion of his offering. 'I saw it as an operatic exercise', he explained after the concert. 'Imagine it as a character on stage delivering an operatic aria, and opera is my thing'. Writing in the Independent on Sunday (18 July) George Hall proclaimed Todd's contribution as 'In first place', in his scorecard of 'winners of the evening' - all inevitably British of course.

I myself felt there were in fact no winners or losers, but just 20 very valid contributions, but sadly no room to mention them all. Of those not already referred to, I particularly enjoyed Edward McGuire's setting of his own poem of domestic bliss on early rising, Redgate's quizzical setting of Beckett, Bob Chilcott's 'L'enfant dort', Michael Finnissy's 'Salomé' and Judith Bingham's structurally traditional setting of Hérédia's 'La Jeune Morte', which came across with her customary verve and impact. Last but not least, the concert, attended by a large audience including all 20 composers, closed on nocturnal note, with Edward Cowie's unusually graphic Owl in 'Les Hiboux'.

Jill Barlow 
Three London reports

\section{1) Conway Hall: Ronald Stevenson's Bax Variations}

A piano recital that begins with three Bax miniatures, continues with Ronald Stevenson's Peter Grimes Fantasy and a Stevenson first performance, and fills a parallel second half with three Debussy studies, the Busoni Carmen Fantasy and the Rachmaninov Corelli Variations (ingenious programming!) might not be calculated to sell the place out - the Conway Hall on this occasion, on 4 May, for a concert given by Jeremy Limb - but it guarantees those who do turn up a high-protein diet. The main course, Stevenson's Fugue, Variations and Epilogue on a Theme of Bax, was a long time in the cooking: begun in 1983, it was finalized only two decades later, in the last months of 2003, in response to a request from the Finnish pianist Matti Raekallio. That the prize of the first performance went to Limb (b. 1971) is nonetheless appropriate enough: he is Bax's great-grandson.

Much of the music of both Bax and Stevenson inhabits a clearly Celtic aesthetic, and Stevenson's new piece, not quite 20 minutes in length, emerges from this world of half-colours and harmonic refinement - the theme, taken from the second movement of Bax's Second Symphony, composed in 1924, is instantly recognisable as Celtic, as is the development to which Stevenson treats it.

Stevenson believes, logically enough, that his listener's ears are at their freshest at the beginning of a work, and so that where he prefers to site his fugues. This one is free (it is marked 'without protocol'), the entries not always immediately apparent to the ear - it's a sort of subterfugue, if you like; indeed, the entire structure is plastic and supple. The music emerges from the bass, slowly, hesitantly, singing modally of mournful places, its frequent recourse to bitonality producing biting dissonance, and sonorous bass passages alternating with peppery passage-work in the treble as a fanfare, with just a hint of Spanishry, crowns the fugue. The variations creep in nervously, the theme shadowed by its own shape, as if looking over its shoulder, trying to articulate a lonely hill song. A sardonic, impish jig precedes a funereal elegy, the phrases extended by Lisztian trills. Abrupt, toccata-like figurations characterize the next variation, before the music flows into a broader, more dignified passage, where Stevenson allows the theme its noble head in warmer, less troubled harmonies than those that precede it. With some sort of emotional stability established, a series of calm chords, brief and beautiful, suggest the onset of a chorale; instead, they introduce the Epilogue, where Stevenson takes the time to state Bax's theme in unemphatic decoration. As it sinks into well-earned rest, a brief, Busonian chord threatens disruption, but a final pianissimo chord gently reasserts the harmony and the piece is over.

The Fugue, Variations and Epilogue on a Theme of $B a x$ is an oblique work: its power and craggy strength are immediately obvious; equally obviously, there is all manner of subtlety that will emerge from repeated hearings and further performances - and, as with the rediscovered 1939 Sonata in A, An Riobain Dearg ('The Red Ribbon') by Erik Chisholm, reported in Tempo 58.228, it is a major contribution to a specifically Scots piano literature.

But it wasn't the last première of the evening. Stevenson had suggested to Limb that a theme from the first movement of Bax's Fourth Piano Sonata would make a good fugue subject, and Limb duly composed one, springing it - and its dedication - unannounced on Ronald Stevenson, down from Scotland for the occasion. Limb's sixminute score treads a fine line of emotional ambiguity, beginning in an uneasy lyricism which hints at darker, more passionate feelings below the surface. A brief climax shakes fistfuls of notes out of the pianist's sleeves in a stormy descent of the keyboard before the lyricism returns in singing textures that vaguely evoke Sorabji, Ireland, even the blues; a powerful stretto surges up to close the work in unemphatic strength.

Jeremy Limb couldn't coax much warmth of tone from the unresponsive Conway Hall instrument, sounding in a dead acoustic, too (I'd like to hear what he'd make of the programme somewhere else, with a different piano). What he brought to all the pieces he played was a resolute textural and rhythmic clarity, which proved especially valuable in elucidating Ronald Stevenson's contrapuntal complexities - and his own, which argue that Limb should swap the keyboard for the writing desk more often: he plainly has something to say.

\section{2) Barbican: Poul Ruders' 'Listening Earth'}

Poul Ruders has become something of a specialist in vast orchestral scores portraying powerful natural, even supernatural, phenomena: the apocalyptic (literally) Således saae Johannes ('Thus Saw St John') in 1983-84, Tundra in 1990, Gong in 1992 (the gong in question being the blazing disc of the sun), Fairytale in 2000 and, in 2001, Listening Earth, first performed by the Berlin Philharmonic under David Robertson in November 2002 and given its UK première, again under Robertson's 
capable baton, by the BBC Symphony Orchestra on 6 March.

Listening Earth, a 'symphonic drama' in four sections, was intended as a celebration of life, inspired by the essayist Joseph Addison (1672-1719): 'The Moon takes up the wondrous tale, / And nightly to the list'ning Earth / Repeats the story of her birth'. The work opens with a massive prelude, as a long string melody emerges from convulsive movements in the bass, with chimed percussion adding a tingling gloss. Suddenly the skies clear for a brief violin duo before the earth begins to spawn again; the horn melody from 'Morning' in Peter Grimes can't be accidental. The second section is an edgy nocturne, with long-held string chords and wind lines (and another Britten allusion or two) and the percussion gently chiming away the night.

A sense of threat has been building in the background and suddenly, at Doppio tempo, quaver $=88$ Alla breve tempestuoso, a nervous, haunted scherzo bursts through, whipped on its way by tourbillions from strings and wind and, increasingly, braying brass. Ruders was working on the score when 19 murderers flew into the Twin Towers and 'personally - and as an artist - I could no longer end the piece on a glorious and happy note'. Addison then gave way to Auden's poem 'September 1, 1939': 'The unmentionable odour of death / Offends the September night'. The music suddenly takes on a tragic tone and is brutally assaulted by paroxistic blows from tam tam and bass drum. The strings maintain a stark elegy, with nervous woodwind commentary; a viola sola offers, unconvincingly, some cause for hope - and Listening Earth comes to a bleak and bloodied end.

Bad form to append a review of the latest of Bridge Records' CDs of Ruders' music, ${ }^{2}$ since I wrote the booklet text, but his Fairytale, written to a commission from the Nordic student orchestra Orkester Norden, is such an impressive piece that I cannot let it get away unobserved. Fairytale, Ruders' score explains, is

a tone poem based on a passage from one of Hans Christian Andersen's lesser known fairytales, The Wind Tells about Waldemar Daae and his Daughters, a mighty allegory about the transitoriness of Life, about Vanity and Pride and the inevitable victory of Death (alias the wind), whose scything ravaging is sublimely depicted by Andersen in these few, truly breathtaking lines: 'And

${ }^{2}$ RUDERS: The Music of Poul Ruders, Vol. 4: Fairytale; ${ }^{1}$ Piano Sonata No. $2 ;{ }^{2}$ De Profundis; ${ }^{3}$ Concerto in Pieces. ${ }^{4}{ }^{1}$ Orkester Norden c. Stefan Solyom; ${ }^{2}$ Thomas Adès (pno); ${ }^{3}$ Quattro Mani (pno duo), David Colson (perc); ${ }^{4}$ BBC Symphony Orchestra c. Sir Andrew Davis. Bridge 9143.
Winter rushed, Winter and Summer they rushed, and they rush, like I rush, like the howling snow, the flurrying apple blossom, the scurrying foliage; rush! rush! The people too!'

Ruders' wind, chill and implacable, blows straight down from Tapiola, sweeping in, Presto feroce, from the very first bar in orchestral textures that demand the utmost virtuosity (Ruders was obviously out to prove these kids' mettle). After three minutes stamping triplets from the percussion seem to slow the hurricane, but the underlying pulse pushes on undaunted: the storm merely refreshes itself with a change of texture and piles onwards. Here, too, bass drum and tam-tam try to batter the music into submission, managing initially only in paring a few lines from the texture; unexpectedly, the chase drops to half-speed and a succession of massive clusters spreads from strings to winds and finally envelops the entire orchestra. But nature will not be pinioned: Subito prestissimo, the storm escapes and, ringed around with eddying horns, rushes off to the terse double barline. This is thrilling music, with masterly orchestral writing energized by a raw power that, heard live, must bring up the hair on the nape of your neck. It deserves repertoire status.

\section{3) Conway Hall again: Gerard Schurmann's String Quartet}

Premièred by the Chiligirian Quartet in Conway Hall on 3 October, Gerard Schurmann's String Quartet, was in truth its composer's third foray into the genre: two earlier exemplars, from 1943 and 1946, were withdrawn many years back. Schurmann, a youthful 80 this year, has long been known as a master of the orchestra, on the podium as well as at his desk, but latterly has been increasingly drawn to chamber music, with a Duo for violin and piano, two piano quartets and a trio for clarinet, cello and piano from the past two decades - hardly a telling quantity until one considers that his worklist barely passes the 30 mark

This quartet, some 25 minutes in length, suggests he should have been at it a lot sooner: it is a tightly argued, directly communicative work, thoroughly idiomatic in its use of quartet-texture though over-frequent recourse to unison writing, both in little scalic runs and broad statements, suggests every so often that Schurmann wishes he had a string orchestra to hand.

The first of its four movements opens with a duet between second viola and viola in a dryeyed, reflective Adagio molto cantabile, where they are soon joined by cello and first violin. Occasional surges through the wiry cantilena hint 
at energies below the surface until a repeated four-note figure unlocks a whirlwind Allegro of flying polyphony, intermittently interrupted by stabbing chords, some muscular unisono writing and re-examination of the opening material. A bright, folky dance - it's wonderfully catchy - is quashed by another unison statement, the tension maintained as the tempo repeatedly pushes forward and pulls back. The buoyant dance returns but a further unison passage and two brusque chords shut the movement up.

The tumbling pizzicato scherzo - playfully reminiscent of Britten's Simple Symphony - is answered by some lyrical arco writing in the trio, its melody given an awkward but attractive sway by its articulation in groups of two. The return of the scherzo is silenced rather as the first movement, with a single pizzicato chord.

The third movement, Adagio ed espressivo, begins as a broad dialogue between first violin and cello over long-breathed support from second violin and viola. A half-hearted attempt at a climax falls back into a Bartókian rumination, each instrument - the cello especially - confiding its secrets to the others. Four times the viola initiates further discussion, but the discourse closes, unresolved and uneasy.

The finale sets out with another tough unisono, out of which a spiky Allegro vivace comes barrelling forth before it's eventually brought to a halt by another ruminative passage, edgily lyrical, gently elegiac. The coda comes like a sunburst, with radiant singing lines over spinning figuration. A further series of staccato chords another a device I felt was overused - and another emphatic chord (a decidedly Brittenesque one) seals the action.

My misgivings about certain features of the quartet - chiefly its regular recourse to specific gestures - would very probably be silenced by another hearing: familiarity might well allow me to hear them as integrative rather than repetitive. And one could hear that - for all the passion of the Chilingirians' performance - there's much more to come alive once they're played the work in: the slow movement has an intense glow that somehow stayed below the surface on this first outing. That such deeper layers of meaning can be sensed points to the richness and subtlety of much of the writing; what was immediately obvious was that it shares the same youthful energy that characterizes its 80-year-old composer. Meantime, if those two early quartets were staging posts towards this new work, however distant, it might be worth trying to twist Schurmann's arm into blowing the dust off them and giving them another chance.

Martin Anderson 